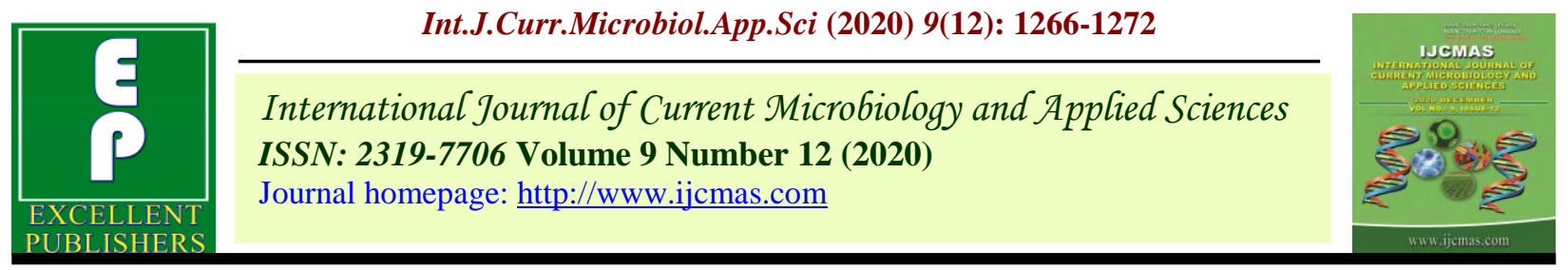

Original Research Article

https://doi.org/10.20546/ijcmas.2020.912.156

\title{
Effect of Organic, Inorganic and Biofertilizers on Yield, Quality and Economics of Guava
}

\author{
Shubham Mangal ${ }^{1}$, S. S. Singh ${ }^{1}$ and Kumudani Sahu ${ }^{2 *}$ \\ ${ }^{1}$ Mahatma Gandhi Chitrakoot Gramodaya Vishwa Vidyalaya, Madhya Pradesh, India \\ ${ }^{2}$ Indira Gandhi Krishi Vishwavidyalaya, Raipur, Chhattisgarh, India \\ *Corresponding author
}

\begin{abstract}
A B S T R A C T

\begin{tabular}{|l|}
\hline Ke y w o r d s \\
$\begin{array}{l}\text { Guava, Yield, } \\
\text { Quality, Economics, } \\
\text { Biofertilizer }\end{array}$ \\
\hline Article Info \\
\hline $\begin{array}{l}\text { Accepted: } \\
\text { 12 November } 2020 \\
\text { Available Online: } \\
\text { 10 December } 2020\end{array}$ \\
\hline \hline
\end{tabular}

An experiment was conducted to assess the effect of organic, inorganic and bio-fertilizers on yield, quality and economics of guava (Psidium guajava L.) during 2014-15. Result exhibited maximum total soluble solids $\left(11.37^{\circ}\right.$ Brix) in T4 (100\% recommended dose of $\mathrm{NPK}+50 \mathrm{~kg}$ FYM $+150 \mathrm{~g}$ Azotobacter $+100 \mathrm{~g}$ PSB). The lowest $\mathrm{pH}$ (4.21) was recorded in T4 $(100 \%$ recommended dose of NPK $+50 \mathrm{~kg}$ FYM $+150 \mathrm{~g}$ Azotobacter+100g PSB). The highest ascorbic acid was found in T13 (50\% Recommended dose of NPK $+50 \mathrm{~kg}$ FYM $+150 \mathrm{~kg}$ Azotobacter $+100 \mathrm{~g}$ PSB).The higher total acidity (0.58\%) was recorded with T4 (100\% recommended dose of NPK + 50kg FYM $+150 \mathrm{~g}$ Azotobacter $+100 \mathrm{~g}$ PSB).The maximum (147.78) of fruits yield (q/ha) was obtained in T5 - 100\% ecommended dose of NPK + 50kg FYM + 150g Azotobacter + 100g PSB and maximum Cost : Benefit ratio (1:3.53) was recorded in $\mathrm{T} 5$.
\end{abstract}

\section{Introduction}

Guava (Psidium guajava L.) is one of the most important and extensively cultivated tropical crops of India. It is good source of vitamin-C, pectin, also contains fair amount of calcium and widely used for making of jelly. The ascorbic acid content of guava is four-five times higher than the citrus fruit. It is hardy fruit which can be grown in alkaline and poorly drained soil. Important guava growing states in the country are Uttar Pradesh, Bihar, Madhya Pradesh, Maharashtra, Andhra Pradesh, West Bengal, Tamil Nadu, Gujrat, Punjab, Assam, Karnataka, Orissa, Kerala and Rajasthan.
Allahabad district of Uttar Pradesh has the reputation of growing the best quality of guava fruits in the world (Lal and Das, 2017). The three times flowering seasons have been observed in North Indian conditions while two flowering seasons have been reported in other parts of the country. The flowering may affect with plant age and stress (Lal and Nath, 2020b) as well as phenolics content (Lal et $a l ., 2019 \mathrm{a})$. Guava is self pollinated crops but cross pollination also occur to some extent and success of fruit set depend on pollen grains used in pollination (Lal et al., 2019b and c). The continuous harvesting of the fruit may affect the quality production but it may be maintained through crop regulation (Lal et 
al., 2017a), plant growth regulator application (Lal et al., 2013 and 2017). However, weather condition and fruit drop may affect yield and quality of fruits (Lal and Nath, 2020a; Lal et al., 2017b). Intensive agriculture is today's demand to meet the requirement by growing populations but it dramatically increases deforestation and conversion of grassland to agriculture, soil degradation by increasing soil erosion, compaction, crusting and water logging, salinization, alkalisation, acidification, soil pollution and nutrient depletion, reduction of organic matter content in the soil and poisoning water with agricultural chemicals (Sahu et al., 2019). The tremendous use of chemical fertilizers affects soil properties. The efficient soil microbes play an important role, since they are responsible to drive various biological transformations and different pools of carbon (C) and macro- and micronutrients, which facilitate the subsequent establishment of soilplant-microbe interaction (Sahu et al., 2017). Organic materials help to maintain the population of soil microbes. Application of biofertilizers increases minerals and water uptake, root development, vegetative growth and $\mathrm{N}$ - fixations. Nutrition improved in yield and quality in guava (Jayswal et al., 2017b), water melon (Hazarika et al., 2016), cabbage (Kumar et al., 2015a, b). Tracer technique helps to trace the nutrient element in the plants (Diwan et al., 2019). Hence, inorganic and organic as well as biofertilizers are important inputs to boost quality production with minimum hampering into the soil.

\section{Materials and Methods}

An experiment was conducted to assess the effect of organic, inorganic and bio-fertilizers on yield, quality and economics of guava (Psidium guajava L.) during 2014-15 at the Research Farm of KVK Majhgawan, District Satna, MP which is situated in the North-east part of Madhya Pradesh at latitude $24^{\circ} 31 \mathrm{~N}^{\prime}$, longitude $81^{\circ} 15 \mathrm{E}^{\prime}$ and altitude of 306 meters above the mean sea level. The region is semiarid and sub-tropical having hot and dry summer followed by rainy season and cold winter. The average rainfall varies from 3.5 $\mathrm{mm}$ to $79.96 \mathrm{~mm}$. The rainfall is observed mainly from July to September and sometimes winter showers are also received. All the fruits were harvested from the tree and the total weight was taken. Fruit yield was expressed in $\mathrm{kg}$ per tree. The amount of total soluble solids present in the ripened fruit juice was determined by Hand Refractometer and expressed in percentage. The $\mathrm{pH}$ of fruit was measured by digital $\mathrm{pH}$ meter and average value was analyzed. Specific gravity was determined by water displacement method. As per the existing market prices the input and output costs were computed treatment wise and different economics parameters viz., cost of cultivation, gross return, net return and benefit cost ratio were calculated. The data recorded during the course of investigation were subjected to statistical analysis as per method of analysis of variance (Fisher, 1936). The significance of the treatment effect were judged with the help of ' $F$ ' variance ratio test Greater calculated ' $F$ ' value (variance ratio) was compared with the table value, the effect was considered to be significant. The significant difference between the means was tested against the critical difference at 5\% level of significance.

\section{Results and Discussion}

The data on total soluble solids $\left({ }^{\circ}\right.$ Brix) as influenced by different treatments are presented in table 1 . The maximum total soluble solids (11.37 ${ }^{\circ}$ Brix $)$ was recorded with T4 (100\% recommended dose of NPK + $50 \mathrm{~kg}$ FYM + 150g Azotobacter + 100g PSB). The maximum total soluble solids ( ${ }^{\circ}$ Brix) in T4 may be due to the fact that there was more supplement of nutrients to the plants. TSS is not influenced by number of fruits and fruit weight (Lal et al., 2020). Azotobacter and PSB substantially would have added more 
nitrogen and solubilized more phosphorus to plants, respectively. FYM and Vermicopmost contain micronutrients which help in proper development of fruits and fruit quality as well. Similar findings were also reported by Uma et al., (2002) and Ramet et al., (2007).

The lowest $\mathrm{pH}$ (4.21) was recorded in $\mathrm{T} 4$ (100\% recommended dose of NPK $+50 \mathrm{~kg}$ FYM + 150g Azotobacter+100g PSB).The reduction is $\mathrm{pH}$ with application of biofertilizer like (Azotobacter and PSB) may be due to the formation of such metabolites which reduced the acidity percentage in fruits (Gopal and Sen 2001). The highest ascorbic acid was found in T13 (50\% Recommended dose of NPK $+50 \mathrm{~kg}$ FYM $+150 \mathrm{~kg}$ Azotobacter $+100 \mathrm{~g}$ PSB). The higher total acidity $(0.58 \%)$ was recorded with T4 $(100 \%$ recommended dose of NPK + 50kg FYM + $150 \mathrm{~g}$ Azotobacter $+100 \mathrm{~g}$ PSB) which might be due to more number of fruit retention (Nagraj et al., 2019). The results are in confirmation with the application of Azotobacter and PSB which increase the total acidity percentage in guava fruits. This has also been reported by Kirad et al., (2009) and Mitra et al., (2010). The highest TSS $\left(12.07^{0}\right.$ Brix), Ascorbic acid $(244.4 \mathrm{mg} / 100 \mathrm{~g})$, Total Sugar (8.45\%), Reducing Sugar (4.91\%) and Non-Reducing Sugar (3.54\%) was recorded in guava with application of 5 $\mathrm{kg} \mathrm{FYM}+2 \mathrm{~kg} \mathrm{VC}+75 \% \mathrm{RDF}$ \{225:150:150g NPK $\}+$ Azotobactor $150 \mathrm{gm}+$ PSB 100gm / Plant (Jayswal et al., 2017a).Differences in sugar content might be due to maximum conversation of starch into sugar (Lal et al., 2018).

Table.1 Effect of organic, inorganic and bio-fertilizers on quality of fruit

\begin{tabular}{|c|c|c|c|c|}
\hline Treatments & TSS & pH & $\begin{array}{l}\text { Ascorbic acid } \\
(\mathrm{mg} / \mathbf{1 0 0 g})\end{array}$ & $\begin{array}{l}\text { Acidity } \\
(\%)\end{array}$ \\
\hline T1 - $100 \%$ recommended dose of NPK & 7.85 & 5.61 & 164.35 & 0.35 \\
\hline T2 - $100 \%$ Recommended dose of NPK + 10kg Vermicompost & 9.28 & 5.22 & 188.12 & 0.42 \\
\hline T3 - 100\% Recommended dose of NPK + 50kg FYM & 9.59 & 5.16 & 188.9 & 0.44 \\
\hline $\begin{array}{l}\text { T4 - 100\% Recommended dose of NPK + 10kg Vermicompost + } \\
150 \mathrm{~g} \text { Azotobacter }+100 \mathrm{~g} \text { PSB }\end{array}$ & 11.1 & 4.35 & 209.91 & 0.55 \\
\hline $\begin{array}{l}\text { T5 - } 100 \% \text { Recommended dose of NPK + 50kg FYM + 150g } \\
\text { Azotobacter + 100g PSB }\end{array}$ & 11.37 & 4.21 & 213.6 & 0.58 \\
\hline T6 - 75\% Recommended dose of NPK + 10kg Vermicompost & 8.71 & 5.4 & 185.23 & 0.39 \\
\hline $\begin{array}{l}\text { T7 - } 75 \% \text { Recommended dose of NPK + 10kg Vermicompost + } \\
150 \mathrm{~g} \text { Azotobacter }+100 \mathrm{~g} \text { PSB }\end{array}$ & 10.48 & 4.72 & 194 & 0.52 \\
\hline T8 - 75\% Recommended dose of NPK $+50 \mathrm{~kg}$ FYM & 9.13 & 5.35 & 186.16 & 0.41 \\
\hline $\begin{array}{l}\text { T9 - } 75 \% \text { Recommended dose of NPK + } 50 \mathrm{~kg} \mathrm{FYM} \mathrm{+} \mathrm{150g} \\
\text { Azotobacter + 100g PSB }\end{array}$ & 10.72 & 4.5 & 203.25 & 0.54 \\
\hline T10 - 50\% Recommended dose of NPK + 10kg Vermicompost & 8.07 & 5.55 & 173.16 & 0.36 \\
\hline T11 - 50\% Recommended dose of NPK + 50kg FYM & 8.48 & 5.41 & 184.2 & 0.38 \\
\hline $\begin{array}{l}\text { T12 - 50\% Recommended dose of NPK + 10kg Vermicompost + } \\
150 \mathrm{~g} \text { Azotobacter }+100 \mathrm{~g} \text { PSB }\end{array}$ & 9.79 & 5 & 190 & 0.46 \\
\hline $\begin{array}{l}\text { T13 }-50 \% \text { Recommended dose of NPK + } 50 \mathrm{~kg} \mathrm{FYM} \mathrm{+} \mathrm{150kg} \\
\text { Azotobacter + 100g PSB }\end{array}$ & 10.09 & 4.9 & 192.63 & 0.48 \\
\hline S.Ed $( \pm)$ & 0.2372 & 0.0463 & 3.0912 & 0.0154 \\
\hline C.D. at $5 \%$ & 0.4896 & 0.0957 & 6.3803 & 0.0319 \\
\hline
\end{tabular}


Table.2 Effect of organic, inorganic and bio-fertilizers on economics of fruit

\begin{tabular}{|c|c|c|c|c|c|c|}
\hline Treatments & $\begin{array}{l}\text { Fruit } \\
\text { yield } \\
\text { (q/ha) }\end{array}$ & $\begin{array}{l}\text { Selling } \\
\text { price } \\
\text { (Rs/q) }\end{array}$ & $\begin{array}{l}\text { Cross } \\
\text { returns } \\
\text { (Rs./ha) }\end{array}$ & $\begin{array}{c}\text { Cost of } \\
\text { cultivati } \\
\text { on } \\
\text { (Rs./ha) }\end{array}$ & $\begin{array}{l}\text { Net } \\
\text { returns } \\
\text { (Rs./ha) }\end{array}$ & $\begin{array}{l}\text { Benefit } \\
\text { cost } \\
\text { ratio }\end{array}$ \\
\hline T1 - $100 \%$ recommended dose of NPK & 79.24 & 1000 & 79240 & 27881 & 51359 & 2.84 \\
\hline $\begin{array}{c}\text { T2 - 100\% Recommended dose of NPK + } \\
\text { 10kg Vermicompost }\end{array}$ & 125.61 & 1000 & 125610 & 18021 & 87589 & 3.3 \\
\hline $\begin{array}{c}\text { T3 - 100\% Recommended dose of NPK + } \\
50 \mathrm{~kg} \text { FYM }\end{array}$ & 125.9 & 1000 & 125900 & 36461 & 89439 & 3.44 \\
\hline $\begin{array}{c}\text { T4 - 100\% Recommended dose of NPK }+ \\
10 \mathrm{~kg} \text { Vermicompost }+150 \mathrm{~g} \text { Azotobacter } \\
+100 \mathrm{~g} \text { PSB }\end{array}$ & 144.69 & 1000 & 144680 & 43871 & 100809 & 3.19 \\
\hline $\begin{array}{c}\text { T5 }-100 \% \text { Recommended dose of NPK + } \\
\text { 50kg FYM + 150g Azotobacter }+100 \mathrm{~g} \\
\text { PSB }\end{array}$ & 147.78 & 1000 & 147780 & 41861 & 105919 & 3.53 \\
\hline $\begin{array}{c}\text { T6 - 75\% Recommended dose of NPK + } \\
\text { 10kg Vermicompost }\end{array}$ & 121.33 & 1000 & 121340 & 37084 & 84256 & 3.27 \\
\hline $\begin{array}{c}\text { T7 - 75\% Recommended dose of NPK + } \\
10 \mathrm{~kg} \text { Vermicompost }+150 \mathrm{~g} \text { Azotobacter } \\
+100 \mathrm{~g} \text { PSB }\end{array}$ & 137.24 & 1000 & 137240 & 42934 & 94306 & 3.19 \\
\hline $\begin{array}{c}\text { T8 - } 75 \% \text { Recommended dose of NPK } \\
+50 \mathrm{~kg} \text { FYM }\end{array}$ & 124.42 & 1000 & 124420 & 35524 & 88896 & 3.5 \\
\hline $\begin{array}{c}\text { T9 - } 75 \% \text { Recommended dose of NPK + } \\
50 \mathrm{~kg} \text { FYM }+150 \mathrm{~g} \text { Azotobacter }+100 \mathrm{~g} \\
\text { PSB }\end{array}$ & 138.46 & 1000 & 138460 & 41374 & 97086 & 3.34 \\
\hline $\begin{array}{c}\text { T10 - 50\% Recommended dose of NPK + } \\
\text { 10kg Vermicompost }\end{array}$ & 119.74 & 1000 & 119740 & 36142 & 83598 & 3.31 \\
\hline $\begin{array}{l}\text { T11 - 50\% Recommended dose of NPK + } \\
50 \mathrm{~kg} \text { FYM }\end{array}$ & 118.87 & 1000 & 118870 & 34582 & 84288 & 3.43 \\
\hline $\begin{array}{c}\text { T12 - 50\% Recommended dose of NPK + } \\
10 \mathrm{~kg} \text { Vermicompost }+150 \mathrm{~g} \text { Azotobacter } \\
+100 \mathrm{~g} \text { PSB }\end{array}$ & 128.02 & 1000 & 128020 & 41992 & 86028 & 3.04 \\
\hline $\begin{array}{c}\text { T13 - 50\% Recommended dose of NPK + } \\
50 \mathrm{~kg} \mathrm{FYM}+150 \mathrm{~kg} \text { Azotobacter }+100 \mathrm{~g} \\
\text { PSB }\end{array}$ & 133.24 & 1000 & 133240 & 40432 & 92808 & 3.29 \\
\hline
\end{tabular}

There was significant difference among various treatments for fruits yield $(\mathrm{q} / \mathrm{ha})$ in guava (Table 2). The maximum (147.78) of fruits yield (q/ha) was obtained in T5 - 100\% Recommended dose of NPK + 50kg FYM + $150 \mathrm{~g}$ Azotobacter $+100 \mathrm{~g}$ PSB. The maximum fruits yield in T5 may be due to the fact that there was more supplement of nutrients to the plants. Azotobacter and PSB substantially would have added more nitrogen and solubilized more phosphorus to plants, respectively. The increase yield under this treatment was associated with increase the number of fruit, low percentage of fruit drop, 
and more fruit retention as also reports earlier (Lal et al., 2013; Lal and Das, 2017) and other reason might be attributed to the improved soil environment with better moisture status and increased availability of plant nutrients which lead to better uptake of moisture by the plants, resulting in better vegetative growth, development and yield (Kumar et al., 2015c). Plants received congenial environment and produces more carbohydrate in leaves and food materials are transported to fruits. Similar findings were also reported by Aske et al., (2017), Shiurkar et al., (2016a) and Shiurkar et al., (2016b). Maximum gross return per hectare (Rs. $147780)$ was recorded in T4 $(100 \%$ recommended dose of NPK + 50kg FYM + $150 \mathrm{~g}$ Azotobacter $+100 \mathrm{~g}$ PSB) and minimum gross return (Rs. 79240) per hectare was recorded in to $(100 \%$ recommended dose of NPK). Maximum net return per hectare (Rs. $105918.55)$ was recorded in T4 $(100 \%$ recommended dose of NPK + 50kg FYM + $150 \mathrm{~g}$ Azotobacter $+100 \mathrm{~g}$ PSB) and minimum net return (Rs. 51358.55) per hectare was recorded in To (100\% recommended dose of NPK). Maximum Cost : Benefit ratio (1:3.53) was recorded in T4 (100\%recommended dose of NPK + 50kg FYM + 150g Azotobacter + $100 \mathrm{~g}$ PSB) and minimum Cost : Benefit ratio $(1: 2.84)$ was recorded in To $(100 \%$ recommended dose of NPK).The highest (276.03 q ha-1) total yield was observed in soil application at $10 \mathrm{~kg}$ ha-1 of $\mathrm{ZnSO} 4+$ Borax+CuSO4 along with $\mathrm{RDF}$ while, lowest (212.12 q ha-1) total yield was recorded in Control (Aske et al., 2017).The highest fresh weight $(137.59 \mathrm{~g} / \mathrm{m} 2)$ and yield per hectare $(13.73 q / h a)$ was recorded in fenugreek under treatment $50 \mathrm{~kg}$ P2O5 per hectare and highest yield per plot $(0.294 \mathrm{~kg})$ was recorded in treatment $30 \mathrm{kgP} 2 \mathrm{O} 5$ per hectare whereas lowest yield was obtained where there was no application of phosphorous and inoculation of biofrtilizers (Shiurkar et al., 2016a). The highest cost benefit ratio was obtained in fenugreek with the treatment $50 \mathrm{~kg}$ P2O5 per ha + Rhizobium + PSB (Shiurkar et al., 2016b).

It can be concluded that treatment T5(100\% recommended dose of NPK, 50kg FYM + 150g Azotobacter +- 100g PSB) recorded as best treatment in terms of better growth, yield and quality of guava. This treatment can be considered most appropriate for integrated nutrient management of guava in this region which is economic with a benefits cost ratio of $(1: 3.53)$.

\section{References}

Aske, V., Jain, P.K., Lal, N. and Shiurkar, G. 2017.Effect of Micronutrients on Yield, Quality and Storability of Onion cv. Bhima Super. Trends in Biosciences, 10(6): 1354-1358.

Diwan, G., Sahu, N. and Lal, N.2019.Role of radioisotopes in agriculture Marumegh: Volume 4(4): 22-27.

Fisher, R.A. 1936. Statistical Method for research workers, ISBN-0-05- 002170.

GopalLalSen, N.L. 2001. Effect of N, Zn and Mn fertilization in fruit quality of guava (Psidium guajava L.) cv. Allahabad Safeda. Haryana J. Hort. Sci.30: 209-210.

Hazarika, M., Phookan, D.B., Lal, N. and Sinha, K. 2016. Effect of different levels of NPK on yield and yield attributes of water melon (Citrullus lanatus Thunb.). Indian Journal of Arid Horticulture. 11 (1-2): 42-46.

Jayswal, D.K., Sharma, D.P., Sharma, T.R., Dwivedi, A.K., Gontia, A.S. and Lal, N. 2017a. Effect of pruning intensity and nutrition on quality of guava fruit cv. Allahabad Safeda under central Narmada Valley of Madhya Pradesh. International Journal of Chemical Studies, 5(4): 483-486

Jayswal, D.K., Sharma, D.P., Sharma, T.R., 
Dwivedi, A.K., Gontia, A.S. and Lal, N. 2017b. Effect of Pruning intensity and nutrition on NPK content in Guava leaves $c v$. Allahabad Safeda. International Journal of Chemical Studies, 5(4): 487-490

Kirad, K.S., Barche, S., Singh, D.B. 2009. Response of Integrated Nutrient Management in strawberry (Fragaria $\mathrm{x}$ ananassa D). Acta Hort. 842, 653-656.

Kumar, H., Kotoky, U., Lal, N., Kumar, J., Sinha, K. and Anal, A.K.D. 2015c.Effect of Drip Fertigation on Yield and Productivity of Guava (Psidium guajava L.). Trends in Biosciences, 8(2): 555-558.

Kumar, J., Phookan, D.B., Lal, N., Kumar, H., Sinha, K. and Hazarika, M. $2015 a$. Effect of organic manures and biofertilizers on nutritional quality of cabbage (Brassica oleraceavar. capitata). Journal of Eco-friendly Agriculture, 10(2): 114-119.

Kumar, J., Phookan, D.B., Lal, N., Kumar, H., Sinha, K., Hazarika, M., Anal, A.K.D. and Kumar, R. $2015 b$. Effect of organic manure and biofertilizers on yield and yield attributes characteristic of cabbage (Brassica oleracea L. Var. Capitata) cv. Golden Acre. Trends in Biosciences, 8(3):672-677

Lal, N. and Das, R.P. 2017. Effect of plant growth regulators on yield and quality of guava (Psidium guajavaL.) cv. Allahabad Safeda. International Journal of Current Microbiology \& Applied Science, 6(5): 857-863.

Lal, N. and Nath, V. 2020a. Aberrant weather influencing the productivity and quality of litchi under changing climatic condition. National Conference on climate conclave 2020: Scientific \& Environmental Innovation and Implementation of Sustainable Development Goals dated: 7-8 March
2020 Organised by SHEFWEL Society and M.)P. Council of Science and Technology, NIDAN Sarvajan Welfare Society, Bhopal. Pp: 111.

Lal, N. and Nath, V. 2020b. Effect of plant age and stress on flowering in litchi (Litchi chinensis). Current Horticulture, 8 (1): 24-27.

Lal, N., Das, R.P. and Verma, L.R. 2013. Effect of plant growth regulators on flowering and fruit growth of guava (Psidium guajava L) cv. Allahabad Safeda. Asian Journal of Horticulture 8(1):54-56.

Lal, N., Gupta, A.K. and Nath, V. 2017b. Fruit Retention in Different Litchi Germplasm Influenced by Temperature. International Journal of Current Microbiology \& Applied Science, 6(12): 1189-1194.

Lal, N., Gupta, A.K., Marboh, E.S., Kumar, A. and Nath, V. 2019b. Effect of Pollen Grain Sources on Success of hybrids in 'Bedana' Litchi. Journal of Bio- resource and Stress Management, 10(3):241-245.

Lal N, Gupta AK, Marboh ES, Kumar A and Nath V. 2019c. Effect of pollen grain sources on International fruit set and retention in 'Shahi' litchi. Multilogic in Science. 9(29): 152-156.

Lal, N., Kumar, A. and Nath, V. 2020. Quantitative analysis of relationships between panicle size and fruit traits in litchi (Litchi chinensis Sonn.). International Journal of Bio-resource and Stress Management, 11(4), 381386.

Lal, N., Marboh, E.S., Gupta, A.K., Kumar, A., Dubedi, Anal, A.K. and Nath, V. 2019a.Variation in leaf phenol content during flowering in litchi (Litchi chinensis Sonn.). Journal of Experimental Biology and Agricultural Sciences, 7(6): 569 - 573

Lal, N., Pandey, S.K., Nath, V., Gontia, A.S. 
and Sharma, H.L. 2018. Evaluation of litchi (Litchi chinenesis Sonn.) genotypes for fruit quality attributes. International Journal of Chemical Studies, 6(3): 2556-2560.

Lal, N., Sahu, N., Marboh, E.S., Gupta, A.K. and Patel, R.K. 2017a. A Review on Crop Regulation in Fruit Crops. International Journal of Current Microbiology \& Applied Science, 6(7): 4032-4043.

Mitra, S.K., Guvung, M.R., Pathak, P.K. 2010. Integrated nutrient management in high density guava orchards, Acta Hort. Pp. 849-356.

Nagraj, K., Diwan, G. and Lal, N. 2019. Effect of fruit load on yield and quality of litchi (Litchi chinensis Sonn.). Journal of Pharmacognosy and Phytochemistry, 8(6): 1929-1931.

Ram, R.A., Bhriguvanshi, S.R., Pathak, R.K. 2007. Integrated plant nutrient management in guava (Psidium guajavaL.) cv. Sardar, Acta, Hort. 735, $345-350$.

Sahu, N., Obi Reddy, G.P., Kumar, N., Lal, N. and Singh, S.K. 2019. Remote Sensing and GIS applications in Soil Resource Inventory in Advances in
Agriculture Sciences Volume - 14, pp 91-108, edited by

Sahu, N., Vasu, D., Sahu, A., Lal, N. and Singh, S.K. 2017. Strength of Microbes in Nutrient Cycling: A Key to Soil Health in Agriculturally important microbes for sustainable agriculture. Vol-1: Plant-soil-microbes nexus. ISBN 978-981-10-5588-1.Pp 69-86, Edited by Vijay Singh Meena et al., 2017.

Shiurkar, G., Lal, N. and Barcchiya, J. 2016b.Effect of different levels of phosphorus and biofertilizers on growth and economic of fenugreek (Trigonella foenum-graecum L.). Advances in Life Sciences, 5(21): 9964-9968.

Shiurkar, G., Lal, N. and Barcchiya, J. 2016a.Effect of different levels of phosphorus and biofertilizers on yield and quality of fenugreek (Trigonella foenum-graecum $\mathrm{L}$.). Advances in Life Sciences, 5(21): 10059-10063.

Uma Shankar Pathak, R.A., Pathak, R.K. and Ojha, C.M. 2002. Effect of NPK on be yield and fruit quality of guava cv. Sardar. Progress Hort. 34: 1, 49- 55.

\section{How to cite this article:}

Shubham Mangal, S. S. Singh and Kumudani Sahu. 2020. Effect of Organic, Inorganic and Biofertilizers on Yield, Quality and Economics of Guava. Int.J.Curr.Microbiol.App.Sci. 9(12): 1266-1272. doi: https://doi.org/10.20546/ijcmas.2020.912.156 